\title{
Erratum
}

\section{Ethnography of language planning and policy - ERRATUM}

\section{Nancy H. Hornberger, Aldo Anzures, David H. Hanks, Frances Kvietok \& Siwon Lee}

doi: 10.1017/S0261444817000428, Published online by Cambridge University Press, 15 March 2018

Unfortunately the April 2018 issue of the journal contained two errors in this article. Firstly, an incorrect version of Figure 1 was included. The proper version of this figure appears here:

\begin{tabular}{|l|l|l|}
\hline $\begin{array}{l}\text { Approaches } \rightarrow \\
\text { Types } \downarrow\end{array}$ & POLICY PLANNING (on form) & $\begin{array}{l}\text { CULTIVATION PLANNING (on } \\
\text { function) }\end{array}$ \\
\hline $\begin{array}{l}\text { STATUS PLANNING goals } \\
\text { (about uses of language) }\end{array}$ & $\begin{array}{l}\text { Officialization } \\
\text { Nationalization } \\
\text { Standardization (status) } \\
\text { Proscription }\end{array}$ & $\begin{array}{l}\text { Revival (revitalization, reclamation) } \\
\text { Maintenance } \\
\text { Spread } \\
\text { Interlingual Communication } \\
\text { (international, intranational) }\end{array}$ \\
\hline $\begin{array}{l}\text { ACQUISITION PLANNING goals } \\
\text { (about users of language) }\end{array}$ & $\begin{array}{l}\text { Group } \\
\text { Education/School } \\
\text { Literary } \\
\text { Religious } \\
\text { Mass Media } \\
\text { Work }\end{array}$ & $\begin{array}{l}\text { Reacquisition } \\
\text { Maintenance } \\
\text { Shift } \\
\text { Foreign language/second language/ } \\
\text { literacy }\end{array}$ \\
\hline $\begin{array}{l}\text { CORPUS PLANNING goals } \\
\text { (about language) }\end{array}$ & $\begin{array}{l}\text { Standardization (corpus, auxiliary code) } \\
\text { Graphization }\end{array}$ & $\begin{array}{l}\text { Modernization (lexical, stylistic) } \\
\text { Renovation (purification, reform, stylistic } \\
\text { simplification, terminology unification) }\end{array}$ \\
& & \\
\hline
\end{tabular}

Figure 1 Language planning and policy: An integrative framework of approaches, types, and goals Note: Figure 1 is reprinted, with minor modifications, from Hornberger (1994), with permission from Multilingual Matters, UK. 
Secondly, the following sentence failed to properly incorporate a requested change from the author:

Original text (page 161):

Bottom-up language planning for Indigenous languages in educational contexts may make use of economic and practical resources top-down policy provisions for economic and practical resources to put Indigenous languages in school (Ferguson 2010), present an explicit alternative to top-down policies created by outsiders in international education development contexts (Nagai 1999), or even develop Indigenous language education in spite of lack of top-down policy support (Patrick, Budach \& Muckpaloo 2013).

The Editor apologises for these errors.

\section{Correction:}

Bottom-up language planning for Indigenous languages in educational contexts may make use of top-down policy provisions for economic and practical resources to put Indigenous languages in school (Ferguson 2010). It may also present an explicit alternative to top-down policies created by outsiders in international education development contexts (Nagai 1999), or even develop Indigenous language education in spite of lack of top-down policy support (Patrick, Budach \& Muckpaloo 2013).

\section{Reference}

Hornberger, N., Tapia, A., Hanks, D., Dueñas, F., \& Lee, S. (2018). Ethnography of language planning and policy. Language Teaching, 51(2), 152-186. doi:10.1017/S0261444817000428 